\title{
39 東北地方におけるヒトスジシマカの分布域拡大と関連する要因
}

\section{小林睦生・二瓶直子・栗原 毅 (国立感染研・昆虫医科学)}

Factors influencing establishment of Aedes albopictus in Tohoku District, Japan

Kobayashi, M., Nihei, N., Kurihara, T.

2001年のヒトスジシマカ $(\mathrm{Aa})$ の分布調査で, 横手 (2/29コロニー, 9.5\%), 新庄 $(11 / 12$, $91.7 \%)$ ，気仙沼 $(4 / 18,22.2 \%)$ で新たに分布が確認された，その後 2 年が経過して 2003 年に はどの程度定着したかを確認するため再調査を行い，また継続して湯沢，盛岡，花巻，北上， 釜石等で調査を行った。新庄ではAaは13/14コロニー（93\%）で，市内広範に広がっていたが， 横手では5/50（10.0\%）がAaであり，分布は市内の一部に限局していた。盛岡では過去数回 の調査でAaは全く認められなかったが，今回初めて市内の 1 寺院で確認された $(2 / 51,3.9 \%)$. なお, 湯沢, 花巻, 北上, 大船渡, 釜石ではAaは確認されず, 小水域に発生する幼虫のほと んどはヤマトヤブカであった。北限域のヒトスジシマカの定着がどのような要因と関連する か検討している。

\section{0 パプア・ニューギニアにおけるマラリア媒介蚊の調査（3) East Sepik 州に おける human- bait collection}

○村主節雄・藤本千草・原田正和（香川大・医・国際医動物）

Survey on the vector mosquitoes of malaria in Papua New Guinea (3)Human-bait collections in East Sepik Province

Suguri, S., Fujimoto, C., Harada, M.

Papua New Guinia のEast Sepik 州の10ケ所（延べ13ケ所）において平成14年 2 月, 平成15年 2 月， 8 月にマラリアの媒介蚊の調査を行った。 方法は人任法を用い， 2 人 1 組で 2 時間毎 のデーターを取った。延べ109人の採集結果3,403匹が採集された。蚊の種類はAnopheles farauti, punctulatus, koliensis, bancroftiの 4 種であり, その内訳はAn. farautiが2,233匹, An. koliensisが985匹, An. punctulatusが182匹, An. bancroftiが 3 匹であった. 島においてはfarauti が 9 割以上を示め, koliensisが約 1 割であった。海岸地方ではfarautiとkoliensisがほほ同数採 集され，丘陵地帯と平原部ではkoliensisが優先種で次いでpunctulatusであった。これに反し高 速道路地帯ではpunctulatusが優先種でkoliensisがこれに次いでいた。共同研究者：Francis Hombhanje and Andrew Masta (School of Medicine and Health Sciencies, UPNG) - Ilomo Hwaihwanje (Wewak General Hospital) - 塚原高広 - 大澤彦太（東京女子医大・国際環境熱帯医 学講座) 